\title{
DNB Working Paper
}

No. I74 / April 2008

Iman van Lelyveld and Klaas Knot

\section{Do financial conglomerates create or destroy value? Evidence for the EU}

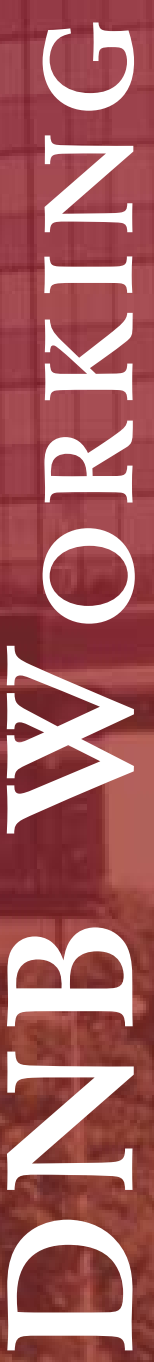




\section{Do financial conglomerates create or destroy value? Evidence for the EU}

Iman van Lelyveld and Klaas Knot*

* Views expressed are those of the authors and do not necessarily reflect official positions of De Nederlandsche Bank.

Working Paper No. 174/2008

April 2008
De Nederlandsche Bank NV

P.O. Box 98

1000 AB AMSTERDAM

The Netherlands 


\title{
Do financial conglomerates create or destroy value? Evidence for the EU
}

\author{
Iman van Lelyveld** and Klaas Knot**
}

April 2008

\begin{abstract}
There is an ongoing debate whether firm focus creates or destroys shareholder value. Earlier literature has shown significant diversification discounts: firms that engage in multiple activities are valued less. Various factors are important in the size of the discount, for example crosssubsidization and agency problems. The extant literature, however, generally focuses on nonfinancial firms or traditional banking (cf Laeven and Levine (2007) and Schmid and Walter (2006)). Our paper focuses specifically on the valuation of bank-insurance conglomerates. We find no universal diversification discount but significant variability. Size, complexity and risk seem to be important determinants.
\end{abstract}

JEL codes: $\quad \mathrm{G} 2, \mathrm{G} 3, \mathrm{~L} 2$

Key words: financial conglomerates, firm valuation

- De Nederlandsche Bank, Supervisory Policy Division, P.O. Box 98, 1000 AB Amsterdam, The Netherlands. Tel.: +31 20524 2024. Email: i.p.p.van.lelyveld@ dnb.nl.

- Nijmegen School of Management, Radboud University, P.O. Box 9108, 6500 HK, Nijmegen, The Netherlands.

* University of Groningen, P.O. Box 800, 9700AV Groningen, The Netherlands. The contents of this working paper reflect the opinions of the individual authors and do not necessarily reflect the views of De Nederlandsche Bank. The authors would like to thank Jack Bekooij for excellent research assistance and Lammertjan Dam, John Lewis and participants of the DNB Workshop on Insurance 2007 and CIBIF 2007 conference for useful comments. 


\section{Introduction}

In this paper we analyze the valuation of the mixed financial conglomerate model on the stock market. Are firms that combine banking and insurance within a single institution valued more or less than the sum of their constituting parts? The financial conglomerate business model, mixing banking and insurance, is not universally applauded. In many countries it is a limited phenomenon, oftentimes a mere temporary one as well. During the 1990s, German Allianz took over Dresdner bank, ING was created in the Netherland, both Dexia and Fortis in Belgium, and Citigroup in the US. These mergers should be seen against the light of continuing consolidation. In the financial sector in the EU a total of 935 billion euro M\&A activity took place between 1990 and 2003. ${ }^{1}$ A minority of these mergers were across sectors, although still accounting for 130 billion euro. The majority of take-over activity was limited within banking ( \pm 580 billion euro) or within insurance $( \pm 225$ billion euro). Lately there seems to be a trend towards deconglomerisation. ABN Amro sold its insurance leg (limited as it was), Credit Suisse sold Winterthur Italia, and Citigroup sold its Travellers insurance subsidiary.

More broadly, there is an ongoing debate whether a firm's focus creates or destroys value. Earlier literature (Lang and Stulz (1994), Berger and Ofek (1995), Servaes (1996)), has shown significant diversification discounts: firms that engage in multiple activities are valued less. What drives the discount is not clearly established, however, and various factors have been highlighted. For instance, Denis, et al. (1997) point to agency problems while Schmid and Walter (2006) highlight geographic diversification. An important strand of the literature argues that the same traits that induce firms to diversify, also lowers the firm values. This sample selection bias has been tackled by Campa and Kedia (2002), Villalonga (2004) and Lamont and Polk (2001).

The extant literature generally focuses on non-financial firms. Furthermore, the few papers that do analyse financial firms (cf Laeven and Levine (2007) and Schmid and Walter (2006)) mainly focus on banking. Branching across sectoral boundaries into insurance (and vice versa) is only discussed as an aside. Our paper will focus specifically on the valuation of bank-insurance conglomerates.

Our contribution to the debate is that this is the first analysis of the valuation of cross-sectoral groups, combining banking and insurance. Is there a premium or a discount and, if so, what drives this discount? We will investigate three possible explanations: size, mixedness and risk. The set up of the paper is straightforward. Section 2 will discuss the relevant literature. We will then discuss the data used and offer some descriptive statistics in section 3. Sections 4 and 5 turn to the empirical analysis of the key value measures and its main determinants. Section 6 concludes. 


\section{Theory}

The costs and benefits of diversification and firm focus have been discussed extensively. The earlier literature was quite positive, pointing to economies of scale and access to profitable business lines (Chandler (1977)), debt capacity and debt tax shields (Lewellen (1971)) and the creation of internal capital markets, leading to increased investment efficiency (Stein (1997)). These earlier papers were followed by less optimistic theories, highlighting the dark side of diversification. Insiders may for instance expand the range of corporate activities for private gain (Jensen and Meckling (1976)) or diversification might intensify agency problems between insiders and small stockholders (Stulz (1990)). It might also influence the volume of activities (Scharfstein and Stein (2000)), it might lead to bargaining problems (Rajan, et al. (2000)) or it might result in bureaucratic rigidity (Shin and Stulz (1998)).

Given these theoretical reasons to love or hate corporate diversification, there is a sizable empirical literature estimating the discount. One of the first of these being an article by Berger and Ofek (1995). The authors argue that corporate diversification will lead to inefficient investment because of cross-subsidisation between business lines. Using SIC-coded activities, they find a discount of 13 percent to 15 percent. Lins and Servaes (1999), however, find more mixed evidence for the discount using a sample of firms operating in Germany, Japan, and the United Kingdom. Overall, however, most authors find a sizable discount.

Most of the traditional literature focuses on the effects of diversification on cash flows and consequent value of the overall firm. Recently, however, some alternative explanations of the equity price discount for conglomerate firms have been suggested. Lamont and Polk (2001) examine the possibility that diversified firms are faced with required future asset returns that are higher than those of specialized firms. While the range of possible explanations for differential expected returns also includes risk, taxes, and liquidity, in a financial conglomerate setting it is often attributed to mispricing by irrational investors. Financial conglomerates are complex, financial products opaque, and so investors and analysts have above-average difficulty in valuing such firms (see for instance the discussion in Hadlock, et al. (1999)).

Mansi and Reeb (2002) point to the classical conflict of interest between shareholders and debtholders when it comes to the determination of the risk profile of the firm. Corporate diversification leads to risk reduction and a lower default premium, which increases debtholder value. In a contingent claims framework, however, shareholder value is the call option on the value of the firm exercised in states where the value of the assets is greater than the debt claim (i.e. the

\footnotetext{
${ }^{1}$ See Dierick (2004).
} 
residual value). The value of this option decreases as a firm decreases its risk, so that in effect value is transferred from shareholders to debtholders.

A radically different view is that it is not corporate diversification that causes the discount but that already discounted firms tend to diversify away from industries experiencing difficulties into more promising industries (reverse causality). Using various econometric techniques, Campa and Kedia (2002), Villalonga (2004), Whited (2001), Fluck and Lynch (1999), and Lamont and Polk (2001) all find that the discount can be at least partly explained by selection bias, endogeneity problems, and measurement error. A similar argument is made by Maksimovic and Phillips (2002): less productive firms tend to diversify, but diversity is not causing the discount.

Most of the literature uses data for non-financial firms. More specifically, financials are generally excluded as for instance their leverage is of such a different magnitude. Exceptions are Laeven and Levine (2007) and Schmid and Walter (2006). The former authors find strong evidence of a conglomerate discount using a sample of 836 banks from 43 different countries. They assign the balance sheet data, taken from BankScope, to different types of activities and compare the bank's Tobin's q to a benchmark of focused firms. Laeven and Levine attribute the destruction of value to agency problems with the conglomerate structure. They also conclude that the size of the discount is such that it most certainly would wipe out any economies of scope these firms might have. Schmid and Walter (2006) limit their sample to the US but include all types of financial intermediaries. ${ }^{2}$ They find a substantial and persistent discount. The authors argue that it is driven by diversification, not by troubled firms diversifying away into more promising areas. For the very largest of the firms in their sample, Schmid and Walter find a substantial premium, pointing to the existence of "too big to fail" guarantees. ${ }^{3}$

\section{Data and descriptive statistics}

A first decision needed before we can construct a data set is what definition to use for financial conglomerates. An obvious definition of a financial conglomerate is a group of firms that predominantly deal with finance (that is, banks). In financial regulation, however, it has acquired a slightly different meaning: a financial conglomerate has come to mean a group of firms that engage in financial activities that have been kept separate, by law and regulation, for many years in many countries. Combinations of some of these activities — banking, securities trading, and insuranceare still forbidden in many countries. The Group of Ten gives the following definition: "any group of companies under common control whose exclusive or predominant activities consist of

\footnotetext{
${ }^{2}$ Commercial banks and bank holding companies, insurance companies, asset managers and broker-dealers.
} 
providing significant services in at least two different financial sectors (banking, securities, and insurance)." ${ }^{\prime 4}$ The European Commission has proposed a more precise definition, in two steps: a group only qualifies as a financial conglomerate if (a) more than 50 percent of group activities are financial and if (b) the shares of the banking sector (including security activities) and the insurance sector in the total of the financial activities are within the range 10-90 percent. In addition, if the minority share has a balance sheet larger than $€ 6$ billion, the group also qualifies as a financial conglomerate. We start our analysis below with the 45 largest financial conglomerates that have been published by the EU in 2006. Where in the remainder of our empirical analysis we will focus on the impact of diversification on market value (sections 4 and beyond), we will filter our conglomerate sample for criteria a) and b), but ignore the second part. ${ }^{5}$ This, together with data availability, results in a list with 29 institutions, shown in Annex 1.

To determine whether conglomerates are valued sufficiently, we also need data for peers solely active in either banking or insurance. To this end we have selected the 45 largest listed banks (based on balance sheet size, 2005), and the 45 largest insurers (based on Gross Premiums written, 2005). For all three groups, banks, insurers and conglomerates we take balance sheet data from the BankScope and ISIS databases, for banks and insurers respectively. For the conglomerates we chose the database with the best cover.

An issue is the treatment of IFRS reporting. Towards the end of the data set there are more and more institutions that report based on the new IFRS guidelines instead of, usually, local GAAP. Visual inspection does not show big jumps as firms move from one reporting framework to the other. We have chosen to use IFRS reports as soon as they are available. ${ }^{6}$

In addition to balance sheet data, we also need data on the market valuation of the firms in our sample. Daily equity data (price index, market value and returns) for the period 1990 to 2005 where taken from Datastream. Finally, we need daily risk free interest rates to construct Sharpe ratio's. These come in two flavours: first, we have 10 year interest rates swaps. Second, we constructed a dataset with the yield on 10 year government bonds. Both these series are taken from Datastream for the period 1990 to 2005 .

\footnotetext{
${ }^{3}$ Schmid and Walter (2006) also analyse the effects of geographic diversification which we will not discuss as our focus is on diversification between banking and insurance.

${ }^{4}$ Group of Ten (2001).

${ }^{5}$ That is, we ignore the financial stability induced requirement that even if the smallest sector is relatively unimportant within the firm, it might still be systemically important. Our interest solely lies with the former. ${ }^{6}$ To capture any undue effects of the change in reporting framework we will use an IFRS dummy, taking on the value 1 for IFRS reports and 0 otherwise. As a sensitivity test we estimated the empirical section using local GAAP reports as long as possible. The results are qualitatively similar.
} 
We determined the percentage of insurance activity (in comparison to banking) based on the annual balance sheet data. In some cases this information was supplemented or confirmed with information from for instance websites. The sector shares were determined based on relative balance sheet size (wata) and on relative sales (wasA), where we took Total Revenue and Gross Premiums Written as measures for sales in the banking and insurance sector, respectively. Although these measures focus on alternative aspects of the relative importance of sectors, their correlation is high $(0.87)$.

To give a broad brush characterisation of our data set we show some descriptives in Table 1 below. Looking at the size of the institutions included, we see that the financial conglomerates are relatively large compared to the included peers. This is natural as firms, both banks and insurers, tend to pick up business across sectors as they grow. Large firms will thus tend to fit our conglomerate criteria.

Table 1 Summary statistics: total assets, 1995-2006, Billions $€$

\begin{tabular}{lllll}
\hline Sector & Mean & Median & Min & Max \\
\hline Banking & 96 & 38 & 0.9 & 992 \\
Insurance & 50 & 14 & 0.4 & 374 \\
Fico & 280 & 116 & 3 & 1170 \\
Total & 105 & 32 & 0.4 & 1170 \\
\hline
\end{tabular}

Source: BankScope, ISIS

How have the conglomerates performed over the years, especially in comparison to their peers? Figure 1 shows the indexed daily stock prices since 1995 of the 135 institutions in our basic sample. ${ }^{7}$ Each of the panes (ie banking, insurance and conglomerate) shows the mean and the median of the indexed price movement. Figure 1 shows that there is material co-movement between the stock price movements of banks, insurers and conglomerates. For all three types there is a steady rise until the second half of the nineties, followed by several years of stabilisation. The worldwide stock market crash shortly after the Millennium is apparent, although a remarkable recovery follows lasting to the end of the sample period.

\footnotetext{
${ }^{7}$ The selection of the 45 listed financial conglomerates was based on the list of the "EU Mixed technical group on supervision of financial conglomerates" as compiled on $13^{\text {th }}$ July 2006 . However, this list is based on the EU-definition and is in two parts: the degree of cross-sector diversification and systemic relevance. As our focus is on the effect of diversification on market valuation we will slightly amend the sample and only consider those observations where conglomerates would qualify based on their degree of diversification instead of financial stability impact.
} 
Figure 1 Price movements for bank, insurers and conglomerates, 1995-2006

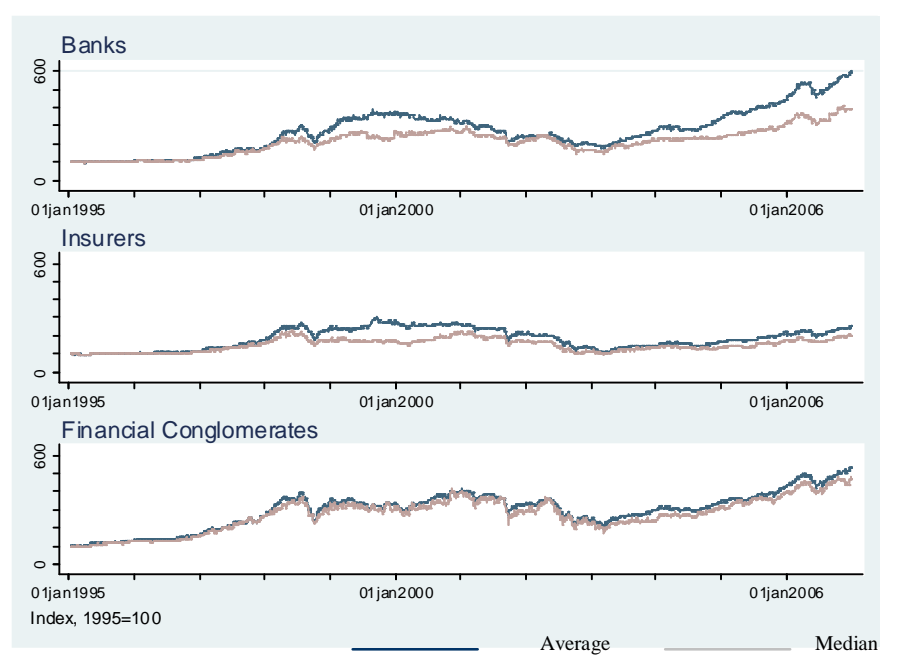

In addition to the stock price movement, investors are also interested in the volatility of particular shares. Figure 2 shows the average volatility within rolling windows of 265 trading days (ie. one year). For the banking sector, it shows a clear increase in investor uncertainty right before the turn of the century, a period where banks faced the Asia/Russia crisis, the LTCM default, and the bursting of the ICT bubble. For insurers, we see a lower level of volatility, clearly linked to the longer term focus of for instance life insurance. It seems, however, that the period of relatively high volatility persists somewhat longer. In particular, it looks like it continues until well after the creeping stock market crash at the start of the century. This is not surprising in the light of insurers' relatively high dependence on investment returns at the time. ${ }^{8}$ Financial conglomerates seem to combine developments in banking and insurance.

Figure 2 The volatility of bank, insurers and conglomerates, 1995-2006

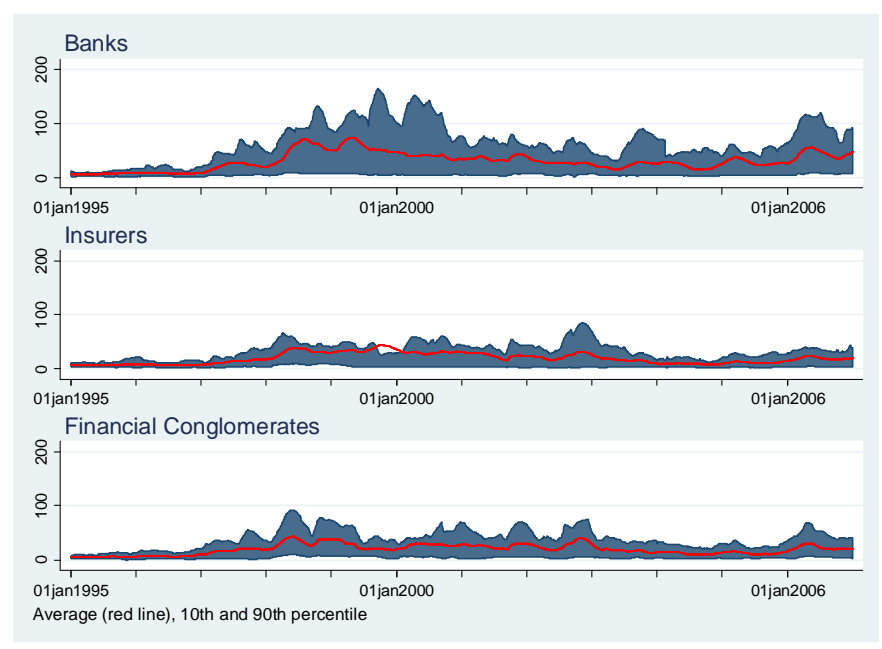

Source: Datastream

${ }^{8}$ Most insurers in the EU have reduced their exposure to markets risks significantly since 2002 by drastically reducing their equity portfolios. See CEIOPS (2005) and CEIOPS (2006). 
Following numerous authors (Berger and Ofek (1995), Lamont and Polk (2001)), our main measure of interest will be the benchmark market-to-book value of financial conglomerates as imputed from the weighted combination of their stand alone valuations, as given by:

$$
\overline{Q_{t}}=\sum_{j=1}^{n} w a_{k j t}\left(\left(\sum_{i=1}^{N_{j}} A_{i t}\right)^{-1} \sum_{i=1}^{N_{j}} A_{i t} Q_{i t}\right)
$$

with $w a$ as the weight for each sector with $k$ being either TA (Total Assets) or SA (Sales) and $n=2$ (banking and insurance); $A_{i}$ stands for assets, $Q_{i}$ for the market-to-book value of each single sector firm, and $N=45$, respectively. Thus, for each conglomerate in our sample, we use the relative weight of banking compared to insurance within the conglomerate (measured by assets or sales) to combine the average market-to-book valuation of stand alone banks and insurers. We also compute an alternative specification of (1) where we compute the median instead of the average market-tobook value for each of the two sectors (changing the part within the brackets). These valuation benchmarks will then be compared to actual conglomerate market-to-book valuation, and subsequently tested for the various theories formulated to explain diversification benefits or discounts such as riskiness, liquidity, mispricing.

Table 2 presents summary statistics. Within each pane we show the summary statistics of the asset weighed mean differences of the natural $\operatorname{logs}$ of $Q$ and both $\bar{Q}$ and $\bar{Q}_{M E D}$, using either the average $(\bar{Q})$ or median $\left(\bar{Q}_{M E D}\right)$ value for the stand alones, and either assets or sales weights for the construction of the benchmark valuations. ${ }^{9}$

Table 2 The relative valuation of financial conglomerates, based on market value / total assets

\begin{tabular}{|c|c|c|c|c|c|c|}
\hline & & Mean & Median & $\begin{array}{l}\text { Standard } \\
\text { deviation }\end{array}$ & Minimum & Maximum \\
\hline \multirow[t]{6}{*}{$Q$} & $\begin{array}{l}\text { Asset weights }\left(w a_{T A}\right) \\
\text { for } \bar{q} \text { and } \bar{q}_{m e d}\end{array}$ & & & & & \\
\hline & $q-\bar{q}$ & -0.0007 & 0.0008 & 0.0612 & -0.2034 & 0.2608 \\
\hline & $q-\bar{q}_{m e d}$ & -0.0010 & 0.0011 & 0.0662 & -0.1846 & 0.3271 \\
\hline & $\begin{array}{l}\text { Sales Weights (wasA) } \\
\text { for } \bar{q} \text { and } \bar{q}_{\text {med }}\end{array}$ & & & & & \\
\hline & $q-\bar{q}$ & 0.0044 & 0.0014 & 0.0686 & -0.2417 & 0.2316 \\
\hline & $q-\bar{q}_{m e d}$ & 0.0039 & 0.0007 & 0.0722 & -0.2221 & 0.2489 \\
\hline
\end{tabular}

The mean value of the relative discount measures is weighed by total assets. $q, \bar{q}$ and $\bar{q}_{\text {med }}$ are natural $\operatorname{logs}$ of $Q, \bar{Q}$ and $\bar{Q}_{M E D}$. The total number of included observations is 142 .

\footnotetext{
${ }^{9}$ Note that as this is a non-linear transformation it implies that the group means shown are not straightforward weighed combinations.
} 
What do the results tell us? Previous research on non-financials firms tends to show clear and significant diversification discounts. For financial conglomerates, most of the existing literature has found more limited discounts. For our sample of $45 \mathrm{EU}$ financial conglomerates we find no evidence of a structural diversification discount. The average asset-weighed excess value is close to zero and statistically insignificantly different from it. It is much more interesting to note that there is sizable variation around these averages. As averages are sensitive to outliers the median might be a better measure of the central effect; all the relevant statistics appear to be comparably insignificant, however. Closer examination of the underlying data reveals that $52 \%$ of the conglomerates show a premium while in $48 \%$ of the cases a discount materialises.

\section{Estimation approach and methodology}

The large variation around the mean of the mean (and median) peers indicates that although on average conglomerates are valued neutrally, this does not hold universally. This led us to investigate whether we could determine specific groups or characteristics that have a significant influence on any discount (or premium). A natural candidate for such a discerning characteristic is size as a proxy for the complexity of the firm. Another such proxy would be the degree to which conglomerates are truly mixed. Finally, the associated risk profile might also be a candidate. We will discuss each of these in turn.

The first discerning characteristic we will discuss is size, proxying for the complexity of the firm. In Figure 3 we have plotted the size of the conglomerates included against $q-\bar{q}$, our measure of relative valuation. In addition we have plotted a regression line, telling us that there seems to be a negative relationship: while small conglomerates witness a premium on average, larger conglomerates tend to face a discount. 
Figure 3 Size versus the conglomerate discount, 1997-2006

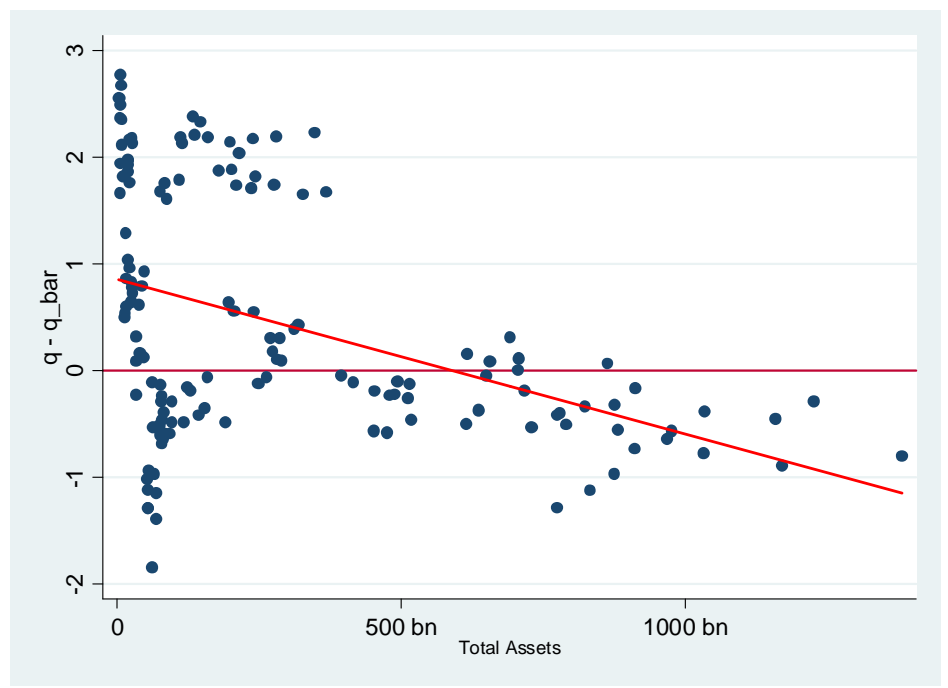

The $\mathrm{R}^{2}$ of the red line is 0.17 .

The second candidate is the degree of mixedness. If, for example, a conglomerate has only $11 \%$ in banking it is likely that market participants will view this conglomerate as an insurer with some "other business". Valuation should in that case be in line with that of its insurance peers. A fully mixed conglomerate (50\%-50\%) might however be seen as a firm that is difficult to manage and to analyse. If this hypothesis holds, we would expect a symmetric relationship sloping down to the 50\%-50\%-point. Figure 4 shows such a line fitted to our data, where the horizontal axis depicts the percentage of assets tied up in insurance. The fit is not particularly strong or robust for either the balance sheet (waтA) or the sales (wasA) measure of sector size. We experimented with different functional forms but these do not materially improve the fit.

Figure 4 "Mixedness" versus the conglomerate discount, 1997-2006

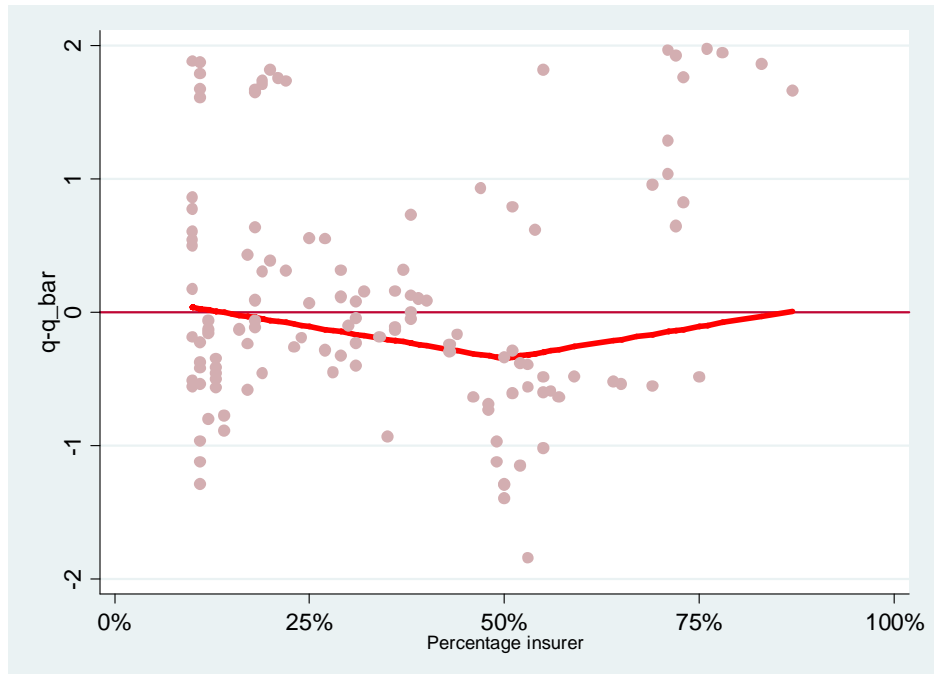

Estimated under the restriction that there should be a symmetrical linear relation around the $50 \%$ mixedness (measured by $w_{\mathrm{TA}_{\mathrm{A}}}$ ). Total assets were used as weigths in the regression. The $\mathrm{R}^{2}$ of the red line is 0.03 . 
The final candidate for explaining the variation in the discount is the riskiness of the firms, as a possible measure for value transfers between shareholders and debtholders. In Figure 5 we plot the standard deviation against $q-\bar{q}$, suggesting indeed that higher riskiness leads to slightly higher stock market valuation on average.

Figure 5 Risk versus the conglomerate discount, 1997-2006

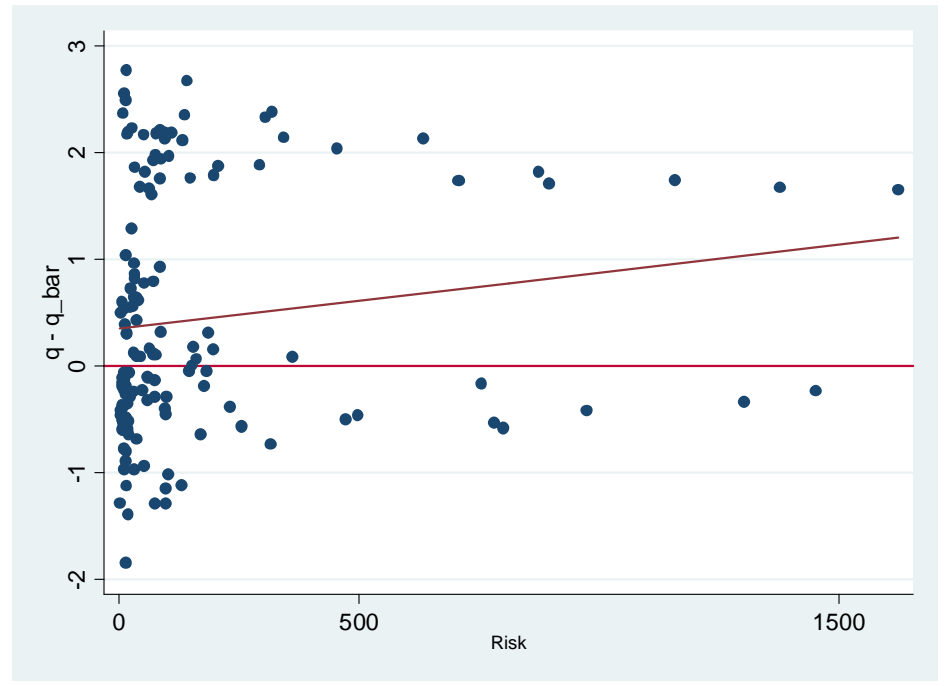

Risk is measured as the standard deviation of equity returns. The $\mathrm{R}^{2}$ of the red line is 0.02 .

An underlying assumption in the panel analysis in the next section is that the data are stationary. We tested this assumption for all the right-hand side variables using a number of tests. The overall conclusion is that the variables are neither all stationary (Hadri (2000) test) nor are all series nonstationary (Pesaran (2003) test). The Taylor and Sarno (1998) test indicates that the series are I(0). However, as the time dimension of our sample is limited, the discriminating power of the tests is limited as well. Furthermore, many of the tests require the panel to be balanced. Forcing this requirement implies dropping many of our conglomerates. 


\section{Empirical results}

We start our multivariate analysis with an analysis in the vein of Berger and Ofek (1995), Lins and Servaes (1999) and Mansi and Reeb (2002). These authors all estimate a relation between corporate diversification and excess value. We estimate the following panel model, both with fixed and random effects.

$$
E V_{i t}=\alpha_{1}+\sum_{k=m+1}^{n} \beta_{k} \text { PRIORS }_{k, i t}+\sum_{l=n+1}^{p} \beta_{l} \operatorname{CONTROLS}_{l, i t}+\varepsilon_{i t}
$$

where

- $\quad \alpha_{l}$ is an intercept term and $\beta_{k, l}$ are coefficient vectors

- $\quad E V$ is excess value, estimated by $q-\bar{q}$ or $q-\bar{q}_{\text {med }}$

- $\quad P R I O R S_{i t}$ is a matrix of variables to test our theoretical priors

- $C O N T R O L S_{i t}$ is a matrix of characteristics related to conglomerate $i$

- $\varepsilon_{\text {it }}$ is the idiosyncratic error, $\varepsilon_{\text {it }} \sim \operatorname{IID}\left(0, \sigma_{\varepsilon}^{2}\right)$

- $\quad i=1, \ldots, N$ where $N$ is the number of conglomerates in the sample

- $t=1, \ldots, T_{i}$ where $T_{i}$ is the number of years in the sample for conglomerate $i$

Our PRIORS cover size, time, the degree of mixedness, and riskiness of the firm. One important starting point is that more complex firms might be valued less, an effect that pops up in two manifestations. Our first prior relates to investors' fear that the "dark side" of diversification (inefficient cross subsidization etc, Berger and Ofek (1995)) will erase any economies of scale and scope. We proxy this by using the size of the firm (the natural log of total assets) and expect a negative sign (larger discounts). The second prior is based on the argument that financial conglomerates are inherently difficult to value, so that investors require a higher rate of return Lamont and Polk (2001). After all, the hybrid firm is a relatively recent phenomenon and does not represent the clear banking or insurance business model that investors traditionally understand and relate to Hadlock, et al. (1999). As both sectors within conglomerate firms become more balanced in size, opacity increases and this ambiguity is likely to erode value. We therefore expect the discount to reach its maximum when the share of the smallest sector approaches its maximum at $50 \%$ (a negative sign on MIXED). ${ }^{10}$ As we would expect analysts to learn and better understand conglomerates over time, we expect a positive sign for the TIME trend also included. The third prior has to do with the riskiness of the firm. As for instance argued in Mansi and Reeb (2002),

\footnotetext{
${ }^{10}$ Note that the MIXED variable employed here differs from the one depicted in Figure 4.
} 
decreasing the riskiness of a firm through diversification will lead to a transfer of value from equity- to debtholders. Equityholders reap the benefits in case of large positive realisations but are protected by their limited liability if bad states of the world materialise. An increase in risk, measured by either the yearly standard deviation of daily returns (RISK) or the LEVERAGE of the firm can then be expected to diminish the discount (positive coefficient).

A first firm-specific CONTROL we include, is relative profitability measured by both return on assets (ROA) and return on equity (ROE). We would expect a positive sign here. Second, we include a dummy variable with the value 1 in years that we use the annual report under the new IFRS reporting rules.

Table 3 Excess value estimation $q-\bar{q}$

\begin{tabular}{|c|c|c|c|c|c|c|c|c|}
\hline & $\begin{array}{l}(3.1) \\
\text { FE }\end{array}$ & $\begin{array}{l}(3.2) \\
R E\end{array}$ & $\begin{array}{l}(3.3) \\
\text { FE }\end{array}$ & $\begin{array}{l}(3.4) \\
\mathrm{RE}\end{array}$ & $\begin{array}{l}(3.5) \\
\text { FE }\end{array}$ & $\begin{array}{l}(3.6) \\
R E\end{array}$ & $\begin{array}{l}(3.7) \\
\text { FE }\end{array}$ & $\begin{array}{l}(3.8) \\
R E\end{array}$ \\
\hline \multicolumn{9}{|l|}{ PRIORS } \\
\hline SIZE & $\begin{array}{l}-0.6708 \\
(0.00)^{* * *}\end{array}$ & $\begin{array}{l}-0.4444 \\
(0.00)^{* * *}\end{array}$ & $\begin{array}{l}-0.6725 \\
(0.00)^{* * *}\end{array}$ & $\begin{array}{l}-0.4483 \\
(0.00)^{* * *}\end{array}$ & $\begin{array}{l}-0.6710 \\
(0.00)^{* * *}\end{array}$ & $\begin{array}{l}-0.4438 \\
(0.00)^{* * *}\end{array}$ & $\begin{array}{l}-0.6726 \\
(0.00)^{* * *}\end{array}$ & $\begin{array}{l}-0.4479 \\
(0.00)^{* * *}\end{array}$ \\
\hline TIME & $\begin{array}{l}0.0867 \\
(0.00)^{* * *}\end{array}$ & $\begin{array}{l}0.0706 \\
(0.00)^{* * *}\end{array}$ & $\begin{array}{l}0.0865 \\
(0.00)^{* * *}\end{array}$ & $\begin{array}{l}0.0703 \\
(0.00)^{* * *}\end{array}$ & $\begin{array}{l}0.0876 \\
(0.00)^{* * *}\end{array}$ & $\begin{array}{l}0.0711 \\
(0.00)^{* * *}\end{array}$ & $\begin{array}{l}0.0874 \\
(0.00)^{* * *}\end{array}$ & $\begin{array}{l}0.0709 \\
(0.00)^{* * *}\end{array}$ \\
\hline MIXED & $\begin{array}{l}-0.9328 \\
(0.06)^{*}\end{array}$ & $\begin{array}{l}-0.4765 \\
(0.29)\end{array}$ & $\begin{array}{l}-0.9097 \\
(0.06)^{*}\end{array}$ & $\begin{array}{l}-0.4756 \\
(0.31)\end{array}$ & & & & \\
\hline MIXED $^{2}$ & & & & & $\begin{array}{l}-28.543 \\
(0.03)^{* *}\end{array}$ & $\begin{array}{l}-13.017 \\
(0.31)\end{array}$ & $\begin{array}{l}-27.746 \\
(0.04)^{* *}\end{array}$ & $\begin{array}{l}-12.942 \\
(0.31)\end{array}$ \\
\hline RISK & $\begin{array}{l}0.0004 \\
(0.03)^{* *}\end{array}$ & $\begin{array}{l}0.0005 \\
(0.01)^{* * *}\end{array}$ & $\begin{array}{l}0.0004 \\
(0.03)^{* *}\end{array}$ & $\begin{array}{l}0.0005 \\
(0.01)^{* * *}\end{array}$ & $\begin{array}{l}0.0004 \\
(0.02)^{* *}\end{array}$ & $\begin{array}{l}0.0005 \\
(0.01)^{* * *}\end{array}$ & $\begin{array}{l}0.0004 \\
(0.03)^{* *}\end{array}$ & $\begin{array}{l}0.0005 \\
(0.01)^{* * *}\end{array}$ \\
\hline LEVERAGE & $\begin{array}{l}0.0498 \\
(0.04)^{* *}\end{array}$ & $\begin{array}{l}0.0487 \\
(0.03)^{* *}\end{array}$ & $\begin{array}{l}0.0467 \\
(0.07)^{*}\end{array}$ & $\begin{array}{l}0.0470 \\
(0.06)^{*}\end{array}$ & $\begin{array}{l}0.0514 \\
(0.04)^{* *}\end{array}$ & $\begin{array}{l}0.0489 \\
(0.05)^{* *}\end{array}$ & $\begin{array}{l}0.0485 \\
(0.06)^{*}\end{array}$ & $\begin{array}{l}0.0473 \\
(0.06)^{*}\end{array}$ \\
\hline CONTROLS & & & & & & & & \\
\hline ROE & & & $\begin{array}{l}-0.0277 \\
(0.47)\end{array}$ & $\begin{array}{l}-0.0221 \\
(0.57)\end{array}$ & & & $\begin{array}{l}-0.0249 \\
(0.52)\end{array}$ & $\begin{array}{l}-0.0212 \\
(0.59)\end{array}$ \\
\hline ROA & $\begin{array}{l}-0.0148 \\
(0.75)\end{array}$ & $\begin{array}{l}-0.0012 \\
(0.98)\end{array}$ & & & $\begin{array}{l}-0.0130 \\
(0.78)\end{array}$ & $\begin{array}{l}-0.0004 \\
(0.99)\end{array}$ & & \\
\hline IFRS & $\begin{array}{l}-0.0529 \\
(0.53)\end{array}$ & $\begin{array}{l}-0.1025 \\
(0.22)\end{array}$ & $\begin{array}{l}-0.0637 \\
(0.46)\end{array}$ & $\begin{array}{l}-0.1158 \\
(0.16)\end{array}$ & $\begin{array}{l}-0.0568 \\
(0.50)\end{array}$ & $\begin{array}{l}-0.1061 \\
(0.20)\end{array}$ & $\begin{array}{l}-0.0667 \\
(0.43)\end{array}$ & $\begin{array}{l}-0.1192 \\
(0.15)\end{array}$ \\
\hline Constant & $\begin{array}{l}76.982 \\
(0.00)^{* * *}\end{array}$ & $\begin{array}{l}51.246 \\
(0.00)^{* * *}\end{array}$ & $\begin{array}{l}76.982 \\
(0.00)^{* * *}\end{array}$ & $\begin{array}{l}51.246 \\
(0.00)^{* * *}\end{array}$ & $\begin{array}{l}76.799 \\
(0.00)^{* * *}\end{array}$ & $\begin{array}{l}51.020 \\
(0.00)^{* * *}\end{array}$ & $\begin{array}{l}77.183 \\
(0.00)^{* * *}\end{array}$ & $\begin{array}{l}51.735 \\
(0.00)^{* * *}\end{array}$ \\
\hline Observations & 135 & 135 & 135 & 135 & 135 & 135 & 135 & 135 \\
\hline Number of id & 25 & 25 & 25 & 25 & 25 & 25 & 25 & 25 \\
\hline R-squared & 0.28 & & 0.28 & & 0.28 & & 0.28 & \\
\hline Hausman & 0.00 & & 0.00 & & 0.00 & & 0.00 & \\
\hline
\end{tabular}

$\mathrm{p}$ values in parentheses, $*$ significant at $10 \% ; * *$ significant at $5 \%$; *** significant at $1 \%$ 
All in all, the results in Table 3 are quite encouraging. The results for $q-\bar{q}$ are for both fixed and random effects. We also estimated the models with $q-\bar{q}_{\text {med }}$, but the results are very similar. ${ }^{11}$ Our first prior, that larger conglomerates have more opportunities for inefficient cross-subsidization and therefore face a larger discount, is strongly confirmed. Our second prior, that the discount would be reduced as conglomerates become less opaque, is also borne out by the data, but somewhat less unambiguously. The TIME trend is significantly positive, suggesting that investors may indeed have increased their appraisal of financial conglomerates over time. The MIXED coefficient has the proper sign but is only marginally significant for the fixed-effects panels. Efforts to test a nonlinear inclusion (MIXED SQUARED) yielded more robust results for the fixed-effects but not for the randomeffects model (columns 5-8). The third prior based on the risk shifting argument also seems to hold. An increase in risk, measured by either the yearly standard deviation of daily returns (RIsk) or the LeVERAGe of a firm positively affects the excess value. Thus, as risks decrease through diversification within a conglomerate, value shifts from equity- to debtholders.

Both the relative return on assets and the relative return on equity remain insignificant throughout all specifications. The IFRS dummy is also not significant, indicating that our results are robust to the change in reporting framework. This is corroborated by broadly similar estimates using an alternative construction of our data set where we use local GAAP reports for as long as they are available and only switch to IFRS if these are no longer available.

A possible criticism of our approach is that the peers chosen are not the relevant ones. In constructing the benchmark $\bar{Q}$ and $\bar{Q}_{M E D}$ we originally used all the peer banks and insurance firms available in our EU sample. It might however be the case that valuation is more regionally determined. The average effect would be filtered out by incorporating panel (or country) specific fixed effects as in our regressions. Comparing the firm specific valuation with banks and insurance firms that are geographically close is another approach. We therefore computed the benchmark $\bar{Q}$ measures for a limited number of banks and insurers that are closest. ${ }^{12}$ Replicating Tables 2 and 3 in this manner lead to materially similar results (available upon request).

\footnotetext{
${ }^{11}$ Note that comparing our results with similar analyses for non-financial firms can be problematic. Tobin's q is measured by dividing the present value of future cash flows by the replacement cost of a firm's tangible assets. In a profitable, non-financial firm the replacements cost would expected to be lower than the net present value of cash flows. Financial firms, however, typically have monetary assets whose replacement values will be in line with the net present value of future cash flows. Tobin's q for financial firms could thus be expected to be lower (if assets are valued on a mark to market basis).

${ }^{12}$ We started by determining the number of banks (insurers) in the home country. If these did not tally up to six we proceeded and included the nearest country and so forth until we had at least six peer banks (insurers). The home countries of the peers can thus differ for the banking peers and the insurance peers.
} 


\section{Conclusion}

We have examined the valuation of financial conglomerates, ie firms that are active in both banking and insurance. Contrasting previous studies we find no universal discount, but we do observe considerable variability around the mean (and/or median) valuation. In a multivariate setting we also report a positive time trend. It might thus be the case that stock markets have only recently begun to better understand and appreciate financial conglomerates.

We discussed three possible explanations for valuation discounts that the existing literature has put forth: inefficient cross-subsidization, opacity of the hybrid conglomerate model, and value shifting between shareholders and debtholders. Our first prior, that larger conglomerates have more opportunities for inefficient cross-subsidization and therefore face a larger discount, is confirmed for our sample of EU mixed financial conglomerates. Our second prior, that the opacity of financial conglomerates would be the main source of observable discounts, is not unambiguously borne out by the data. Our third prior, that value shifts from equity- to debtholders as risk decreases through diversification, does seem to hold. 


\section{Annex $1 \quad$ List of firms in sample}

Financial conglomerates

\begin{tabular}{|c|c|c|c|c|c|c|c|}
\hline Country & Name & $\begin{array}{l}\text { Ave. } \\
\text { watA }\end{array}$ & $\begin{array}{l}\text { Ave. } \\
\text { wasa }\end{array}$ & Country & Name & $\begin{array}{l}\text { Ave. } \\
\text { watA }\end{array}$ & $\begin{array}{l}\text { Ave. } \\
\text { wasA }\end{array}$ \\
\hline $\mathrm{BE}$ & Fortis & 0.14 & 0.31 & IE & $\begin{array}{l}\text { Irish Life \& Permanent } \\
\text { Plc }\end{array}$ & 0.37 & 0.41 \\
\hline $\mathrm{CH}$ & Credit Suisse Group & 0.29 & 0.31 & IT & Banca Carige SpA & 0.09 & 0.08 \\
\hline DE & $\begin{array}{l}\text { Allianz } \\
\text { Aktiengesellschaft }\end{array}$ & 0.68 & 0.95 & IT & Banca Intesa SpA & 0.05 & 0.04 \\
\hline DE & $\begin{array}{l}\text { Wüstenrot \& } \\
\text { Württembergische }\end{array}$ & 0.48 & 0.55 & IT & Mediolanum & 0.66 & 0.78 \\
\hline DK & Alm. Brand A/S & 0.63 & 0.50 & IT & San Paolo-IMI & 0.04 & 0.02 \\
\hline DK & Danske Bank A/S & 0.20 & 0.24 & NL & ING Groep NV & 0.33 & 0.62 \\
\hline FR & $\begin{array}{l}\text { Crédit Agricole - Crédit } \\
\text { Agricole Group }\end{array}$ & 0.12 & 0.11 & SE & Nordea Bank AB & 0.08 & 0.11 \\
\hline GB & Lloyds TSB Group Plc & 0.21 & 0.07 & SE & $\begin{array}{l}\text { Skandinaviska Enskilda } \\
\text { Banken AB }\end{array}$ & 0.07 & 0.12 \\
\hline GB & Old Mutual Plc & 0.60 & 0.68 & SE & Svenska Handelsbanken & 0.10 & 0.35 \\
\hline GB & HBOS Plc & 0.11 & 0.07 & & & & \\
\hline
\end{tabular}

The full list was published by the EU Mixed Technical Group on Supervision of Financial Conglomerates on July 13, 2006. See footnote 5 for our selection criteria. The reported weights $w a$ (total assets and sales, respectively) refer to the average share of insurance in the conglomerate.

\section{Banks}

\begin{tabular}{|c|c|c|c|}
\hline Country & Bank & Country & Bank \\
\hline AT & Bank Austria Creditanstalt AG & GR & Alpha Bank AE \\
\hline AT & Oesterreichische Volksbanken AG & GR & EFG Eurobank Ergasias SA \\
\hline AT & Raiffeisen International Bank-Holding AG & GR & Piraeus Bank SA \\
\hline $\mathrm{CH}$ & Banque Cantonale Vaudoise & IE & Allied Irish Banks plc \\
\hline $\mathrm{CY}$ & $\begin{array}{l}\text { Bank of Cyprus Group-Bank of Cyprus Public } \\
\text { Company Limited }\end{array}$ & IE & Anglo Irish Bank Corporation Plc \\
\hline $\mathrm{DE}$ & Aareal Bank AG & IE & Depfa Bank Plc \\
\hline $\mathrm{DE}$ & $\begin{array}{l}\text { Berlin Hyp-Berlin-Hannoverschen Hypothekenbank } \\
\text { AG }\end{array}$ & IS & Kaupthing Bank hf \\
\hline $\mathrm{DE}$ & Commerzbank AG & IT & $\begin{array}{l}\text { Banca CR Firenze SpA-Cassa di Risparmio di } \\
\text { Firenze SpA }\end{array}$ \\
\hline $\mathrm{DE}$ & Deutsche Bank AG & IT & Banca Lombarda e Piemontese SpA \\
\hline $\mathrm{DE}$ & Deutsche Hypothekenbank (Actien-Gesellschaft) & IT & Banca Nazionale del Lavoro SpA - BNL \\
\hline $\mathrm{DE}$ & Deutsche Postbank AG & IT & Banca popolare dell'Emilia Romagna \\
\hline $\mathrm{DE}$ & Eurohypo AG & IT & Banca Popolare di Milano SCaRL \\
\hline $\mathrm{DE}$ & Hypo Real Estate Holding AG & IT & $\begin{array}{l}\text { Banca Popolare Italiana-Banca Popolare Italiana - } \\
\text { Banca Popolare di Lodi }\end{array}$ \\
\hline $\mathrm{DE}$ & IKB Deutsche Industriebank AG & IT & Banco Popolare di Verona e Novara \\
\hline $\mathrm{DE}$ & LBB Holding AG-Landesbank Berlin Holding AG & IT & Capitalia SpA \\
\hline ES & Banco Espanol de Crédito SA, BANESTO & IT & Credito Emiliano SpA \\
\hline ES & Banco Popular Espanol SA & IT & IFI - Instituto Finanziario Industriale SpA \\
\hline ES & Bankinter SA & NL & ABN Amro Holding NV \\
\hline FI & OKO Pankki Oyj-OKO Bank plc & PT & Banco BPI SA \\
\hline FR & Natexis Banques Populaires & PT & Millennium bcp-Banco Comercial Português, SA \\
\hline
\end{tabular}




\begin{tabular}{llll}
\hline Country & Bank & Country & Bank \\
\hline GB & Alliance \& Leicester Plc & SE & Swedbank AB \\
GB & Bradford \& Bingley Plc & & \\
GB & Northern Rock Plc & & \\
\hline
\end{tabular}

\section{Insurance firms}

\begin{tabular}{|c|c|c|c|}
\hline Country & Insurance firm & Country & Insurance firm \\
\hline AT & Wiener Stadtische Allgemeine Versicherung AG & GB & Amlin plc \\
\hline $\mathrm{CH}$ & Bâloise-Holding & GB & Aviva Plc \\
\hline $\mathrm{CH}$ & Converium Holding Limited & GB & Beazley Group Plc \\
\hline $\mathrm{CH}$ & Helvetia Patria Holding & GB & Brit Insurance Holdings Plc \\
\hline $\mathrm{CH}$ & Schweizerische National VAG & GB & Chaucer Holdings Plc \\
\hline $\mathrm{CH}$ & Swiss Life Holding & GB & Henderson Group Plc \\
\hline $\mathrm{CH}$ & Vaudoise Assurances Holding SA & GB & Hiscox Plc \\
\hline DE & DBV Winterthur Holding AG & GB & Legal \& General Group plc \\
\hline DE & ERGO Versicherungsgruppe AG & GB & Resolution Plc \\
\hline DE & Gerling Beteiligung Gmbh & GB & Royal \& Sun Alliance Insurance Group plc \\
\hline $\mathrm{DE}$ & Hannover Rückversicherungs-Aktiengesellschaft & GB & Wellington Underwriting Plc \\
\hline DE & Kölnische Rückversicherungs Gesellschaft AG & GR & 'The Ethniki' Hellenic General Ins. Company SA \\
\hline DE & Munich Re Group & IT & Alleanza Assicurazioni SpA \\
\hline DE & Nürnberger Beteiligungs-Aktiengsellschaft & IT & Compagnia Assicuratrice Unipol SpA \\
\hline DK & Codan A/S & IT & Fondiaria - SAI SpA \\
\hline DK & Topdanmark A/S & IT & Generali Assicurazioni SpA \\
\hline DK & Tryg Vesta AS & IT & Milano Assicurazioni SpA \\
\hline $\mathrm{ES}$ & Corporación Mapfre & IT & Premafin Finanziaria SpA \\
\hline $\mathrm{ES}$ & Grupo Catalana Occidente SA & IT & Riunione Adriatica di Sicurta SpA - RAS \\
\hline FR & AGF (Group) & IT & Società Cattolica di Assicurazione coop. Arl \\
\hline FR & CNP Assurances & IT & Toro Assicurazioni SpA \\
\hline FR & Euler Hermes & NL & Aegon NV \\
\hline FR & SCOR SA & & \\
\hline
\end{tabular}

\section{References}

Berger, P. G., and E. OfEK (1995): "Diversification's Effect on Firm Value," Journal of Financial Economics, 37, 39-65.

CAMPA, J. M., and S. KeDIA (2002): "Explaining the Diversification Discount," Journal of Finance, 57, 1731-1761.

CEIOPS (2005): "Report on the Financial Stability of the European Insurance Sector," Frankfurt: Committee of European Insurance and Occupational Pensions Supervisors.

- (2006): "Report on the Financial Stability of the European Insurance Sector," Frankfurt: Committee of European Insurance and Occupational Pensions Supervisors.

Chandler, A. D. (1977): The Visible Hand. Cambridge, Massachusetts: Belknap press.

DenIS, D. J., D. K. DENIS, and A. SARIN (1997): "Agency Problems, Equity Ownership, and Corporate Diversification," Journal of Finance, 52, 135.

DIERICK, F. (2004): "The Supervision of Mixed Financial Services Groups in Europe," ECB Occasional Paper, 20.

FluCK, Z., and A. W. LYNCH (1999): "Why Do Firms Merge and Then Divest? A Theory of Financial Synergy," The Journal of Business, 72, 319.

HAdlock, C., J. Houston, and M. RYNGAert (1999): "The Role of Managerial Incentives in Bank Acquisitions," Journal of Banking and Finance, 23, 221-249. 
HADRI, K. (2000): "Testing for Stationarity in Heterogenous Panel Data," The Econometrics Journal, 3, 148161.

Jensen, M. C., and W. H. Meckling (1976): "Theory of the Firm: Managerial Behavior, Agency Costs and Ownership Structure," Journal of Financial Economics, 3, 305-60.

LAeven, L., and R. Levine (2007): "Is There a Diversification Discount in Financial Conglomerates?" Journal of Financial Economics.

Lamont, O. A., and C. PolK (2001): "The Diversification Discount: Cash Flows Versus Returns," Journal of Finance, 56, 1693.

LANG, L. H. P., and R. M. Stulz (1994): "Tobin’S Q, Corporate Diversification, and Firm Performance," Journal of Political Economy, 1248-1280.

LEWELlen, W. (1971): "A Pure Financial Rationale for the Conglomerate Merger," Journal of Finance, 26, 521-537.

Lins, K., and H. SERVAES (1999): "International Evidence on the Value of Corporate Diversification," 54, 2215.

Maksimovic, V., and G. PhiLlips (2002): "Do Conglomerate Firms Allocate Resources Inefficiently across Industries? Theory and Evidence," Journal of Finance, 57, 721-67.

MANSI, S. A., and D. M. REEB (2002): "Corporate Diversification: What Gets Discounted?" Journal of Finance, 57, 2167-2183.

Pesaran, M. H. (2003): "A Simple Panel Unit Root Test in the Presence of Cross Section Dependence," Cambridge Working Papers in Economics, 0346.

RAJAN, R., H. Servaes, and L. Zingales (2000): "The Cost of Diversity: The Diversification Discount and Inefficient Investment," Journal of Finance, 55, 35-80.

SCHARFSTEIN, D. S., and J. C. STEIN (2000): "The Dark Side of Internal Capital Markets: Divisional RentSeeking and Inefficient Investment," Journal of Finance, 55, 2537-64.

SchMid, M. M., and I. WAlter (2006): "Do Financial Conglomerates Create or Destroy Economic Value?" Stern School of Business Working paper.

Servaes, H. (1996): "The Value of Diversification During the Conglomerate Merger Wave," Journal of Finance, 55, 1201-1225.

Shin, H.-H., and R. M. Stulz (1998): "Are Internal Capital Markets Efficient?" Quarterly Journal of Economics, 113, 531.

StEIN, J. C. (1997): "Internal Capital Markets and the Competition for Corporate Resources," Journal of Finance, 52, 111.

Stulz, R. M. (1990): "Managerial Discretion and Optimal Financial Policies," Journal of Financial Economics, 26, 3-27.

TAYLOR, M. P., and L. SARno (1998): "The Behaviour of Real Exchange Rates During the Post-Bretton Woods Period," Journal of International Economics, 46.

VillalongA, B. (2004): "Diversification Discount or Premium? New Evidence from the Business Information Tracking Series," Journal of Finance, 59, 479-506.

— (2004): "Does Diversification Cause the 'Diversification Discount'?" Financial Management, 33, 5-27.

Whited, T. M. (2001): "Is It Inefficient Investment That Causes the Diversification Discount?" Journal of Finance, 56, 1667. 
Previous DNB Working Papers in 2008

No. I63 Carin van der Cruijsen and Sylvester Eijffinger, Actual versus perceived transparency: the case of the European Central Bank

No. I64 Jacob Bikker and Janko Gorter, Performance of the Dutch non-life insurance industry: competition, efficiency and focus

No. i65 Maarten van Rooij and Federica Teppa, Choice or No Choice: What Explains the Attractiveness of Default Options?

No. 166 Peter Wierts, How do Expenditure Rules affect Fiscal Behaviour?

No. 167 Jacob Bikker and Laura Spierdijk, How Banking Competition Changed over Time

No. I68 Willem Heeringa, Optimal life cycle investment with pay-as-you-go pension schemes: a portfolio approach

No. 169 Kerstin Bernoth, Andrew Hughes Hallett and John Lewis, Did fiscal policy makers know what they were doing? Reassessing fiscal policy with real-time data

No. I70 Alan S. Blinder, Michael Ehrmann. Marcel Fratzscher, Jakob de Haan and David-Jan Jansen, Central Bank Communication and Monetary Policy: A Survey of Theory and Evidence

No. i7I M. van Leuvensteijn, C. Kok Sørensen, J.A. Bikker and A.A.R.J.M. van Rixtel, Impact of bank competition on the interest rate pass-through in the euro area

No. 172 Stijn Claessens and Neeltie van Horen, Location Decisions of Foreign Banks and Institutional Competitive Advantage

No. 173 Peter Spreij, Enno Veerman and Peter Vlaar, Multivariate Feller conditions in term structure models: Why do(n't) we care? 


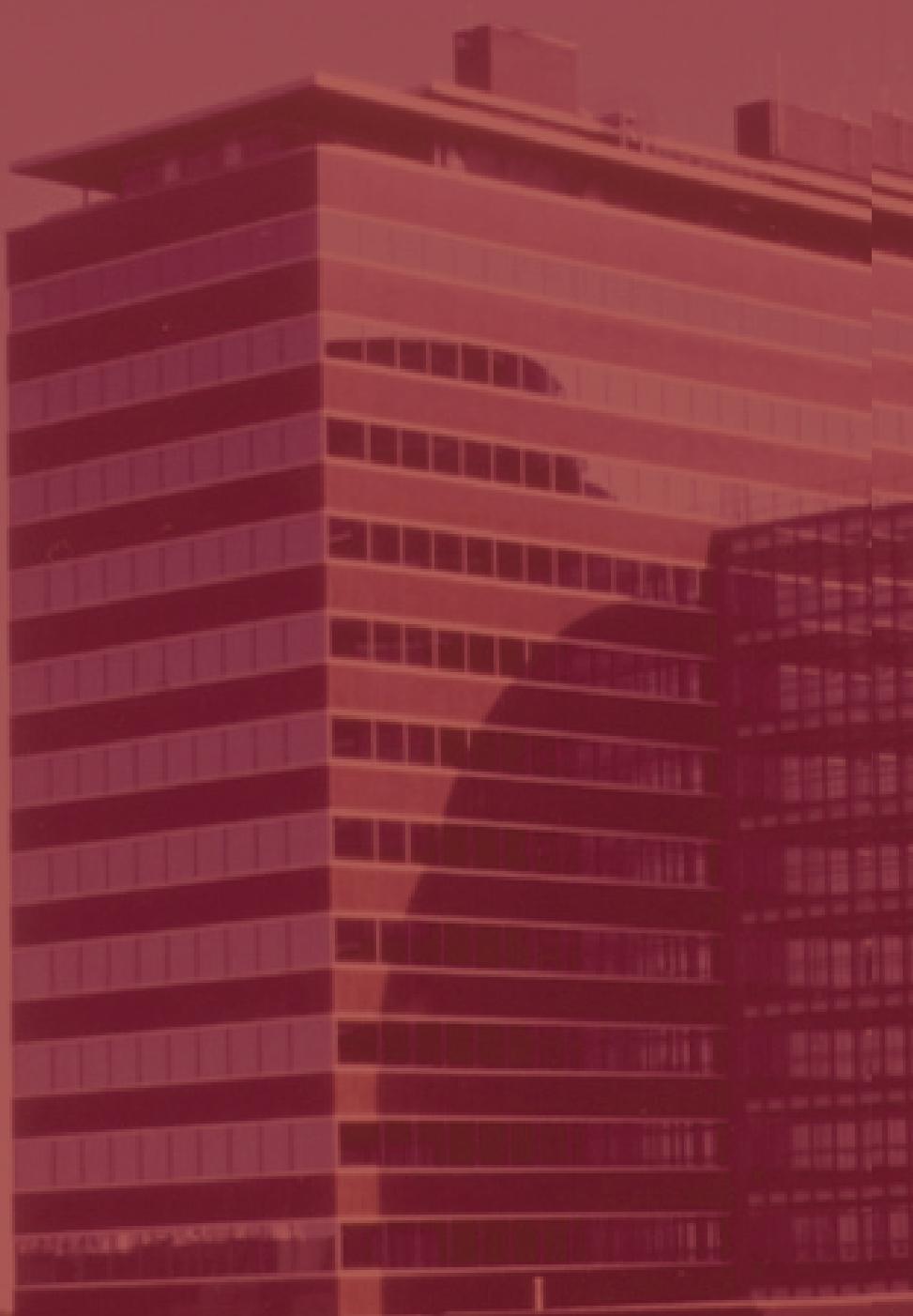

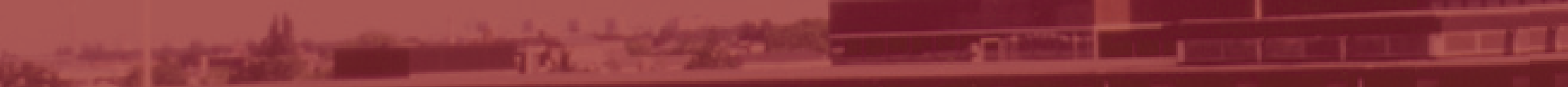

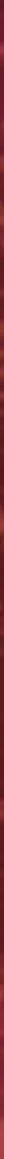

